\title{
Deteksi Kehadiran Mahasiswa Secara Realtime Menggunakan Webcam dengan Metode Viola Jones
}

\author{
Rina Hariani ${ }^{1}$, Nurul Fadillah ${ }^{2}$ \\ ${ }^{1}$ Mahasiswa Progam Studi Teknik Informatika, Fakultas Teknik, Universitas Samudra \\ ${ }^{2}$ Dosen Progam Studi Teknik Informatika, Fakultas Teknik, Universitas Samudra
}

\section{KEYWORDS}

Deteksi, Metode Viola Jones, Deteksi Wajah, Real Time, Mahasiswa.

\section{CORRESPONDENCE}

Phone:

E-mail: a.rinaharinai270597@gmail.com

\section{PENDAHULUAN}

Sistem kehadiran mahasiswa adalah suatu kegiatan atau rutinitas yang dilakukan oleh mahasiswa untuk membuktikan dirinya hadir dalam proses belajar mengajar di suatu kelas di universitas. Pencatatan kehadiran mahasiswa merupakan salah satu faktor penting dalam proses penilaian yang dilakukan dosen pada akhir semester. Beberapa universitas masih menggunakan sistem kehadiran manual misalnya tanda tangan. Pengisian daftar kehadiran secara manual dapat menjadi penghambat pemantauan kedisiplinan mahasiswa dalam hal ketepatan waktu datang dan dapat memicu kecurangan dikalangan mahasiswa.

Dari permasalahan diatas maka Sistem kehadiran mahasiswa manual ditinggalkan dan diganti sistem terkomputerisasi untuk menghindari peluang manipulasi data kehadiran.Sistem kehadiran realtime membutuhkan pendeteksian dan pengenalan obyek secara cepat dengan akurasi yang baik, sehingga metode Viola-Jones dianggap dapat memenuhi kebutuhan tersebut.

Penelitian ini dilakukan dengan menggunakan webcam sehingga hasil yang didapatkan dalam proses pengenalan wajah lebih cepat dan akurat. Namun berbeda dengan proses pengabsenan menggunakan citra, dimana pada prosesnya menggunakan waktu yang cukup lama, karena mahasiswa harus mengambil foto dirinya terlebih dahulu untuk diproses dalam program pengabsenan.Dalam penelitian lain yang dikemukakan oleh TriatmokoAndrianus Hendro menjelaskan tentag "Penggunaan Metode Viola-Jones dan Algoritma Eigen Eyes dalam Sistem Kehadiran Pegawai" Pada penelitian tersebut dikemukakan bahwa Metode Viola-Jones merupakan metode pendeteksian objek hasil dengan akurasi tinggi sekitar 93,7\% dandengan kecepatan yang sangat tinggi sekitar 0,067 detik[7]. Dari penelitian dapat disimpulkan bahwa penggunaan metode viola jones pada penelitian ini sesuai dibandingkan dengan metode yang lain, karena metode viola jones juga menggabungkan beberapa metode seperti Haar Like Feature, Integral Image, Adaboost learning dan Cascade classifier. Dari penelitian diatas dapat disimpulkan bahwa metode yang baik dalam deteksi kehadiran mahasiswa dalam hal ini wajah adalah viola jonesdan belum ada penelitian yang membahas tentang mendeteksi keakuratan metode viola jones tersebut, sehingga muncul suatu ide untuk membuat penelitian tentang mendeteksi keakuratan objek wajah secara realtime dengan menggunakan metode viola jones. 


\section{LANDASAN TEORI}

\section{Pengenalan Wajah}

Teknologi pengenalan wajah makin banyak diaplikasikan dalam sistem pengenalan biometrik, pencarian dan pengindeksan database citra dan video digital, sistem keamanan, konferensi video, dan interaksi manusia dengan komputer. Teknik-teknik pengenalan wajah yang dilakukan selama ini banyak yang menggunakan asumsi bahwa data wajah yang tersedia memiliki ukuran yang sama dan latar belakang yang seragam. Di dunia nyata, asumsi ini tidak selalu berlaku karena wajah dapat muncul di dalam citra dengan berbagai ukuran, berbagai posisi, dan latar belakang yang bervariasi (Hjelmas dan Low, 2001).

\section{Deteksi Wajah}

Pendeteksian wajah (face detection) juga merupakan salah satu tahap awal yang sangat penting sebelum dilakukan proses pengenalan wajah (face recognition). Deteksi wajah dapat dipandang sebagai masalah klasifikasi pola dimana inputnya adalah suatu citra dan outputnya adalah label kelas dari citra tersebut. Dalam hal ini terdapat dua label kelas, yaitu wajah dan non-wajah (Sung, 1996).

Secara dasar ada empat pendekatan berbeda dalam permasalahan deteksi wajah [8], yaitu:

1. Metode berbasis pengetahuan: Aturan didapatkan berdasarkan pengetahuan manusia mengenai fitur terdefinisi dari wajah sesorang manusia. Mayoritas dari aturan-aturan ini membahas tentang hubungan antar fitur.

2. Metode invarian fitur: algoritma dirancang untuk mencari fitur struktural dari wajah yang invariant terhadap masalah umum mengenai pose, halangan, ekspresi, kondisi citra, dan pengrotasian.

3. Metode pencocokan template: dengan suatu set sampleyang diberikan, sebuah set pola wajah standar yang serupa dapat dihasilkan. Hubungan antara citra sample dan set pola yang telah didefinisikan dapat dihitung dan digunakan untuk menarik kesimpulan.

4. Metode berbasis penampilan: mirip dengan metode pencocokan template. Tujuannya adalah untuk mendapatkan keakuratan yang lebih tinggi dengan variasi yang lebih besar pada data latih

\section{Metode Viola-Jones}

Metode Viola-Jones merupakan metode pendeteksian obyek yang memiliki tingkat keakuratan yang cukup tinggi yaitu sekitar 93,7 \% dengan kecepatan 15 kali lebih cepat daripada detektor Rowley Baluja-Kanade dan kurang lebih 600 kali lebih cepat daripada detektor Schneiderman-Kanade. Metode ini, diusulkan oleh Paul Viola dan Michael Jones pada tahun 2001. Metode Viola-Jones menggabungkan empat kunci utama yaitu Haar Like Feature, Integral Image, Ada boost learning dan Cascade classifier. (Andrianus, 2014).

\section{METODE DIUSULKAN}

Ada beberapa proses yang akan dilakukan dalam penelitian ini. Pertama webcam pada laptop akan mencapture atau menangkap gambar secara realtime dari webcam. Lalu setelah kamera laptop menangkap gambar, berdasarkan judul penelitian ini maka kamera akan mendeteksi wajah secara realtime menggunakan metode viola jones, sebagai contoh dari penelitian ini kami sampel wajah manusia. Setelah wajah manusia tercapture oleh kamera webcam langkah selanjutnya masuk kedalam proses membaca sampel gambar menggunakan metode fitur haar dengan dibaca menggunakan OpenCV. Setelah melewati proses membaca sampel gambar menggunakan metode fitur haar selanjutnya kelangkah berikutnya sampel wajah yang telah dibaca lalu diekstrak menggunakan integral image. Selanjutnya ketahap selanjutnya dipelajari data tersebut menggunakan machine learing adaBoost, selama proses pemfilteran, bila ada salah satu filter gagal untuk melewatkan sebuah daerah gambar, maka daerah itu langsung digolongkan sebagai bukan wajah. Namun ketika filter melewatkan sebuah daerah gambar dan sampai melewati semua proses filter yang ada dalam rangkaian filter, maka daerah gambar tersebut digolongkan sebagai wajah. Pada proses selanjutnya Machine Learning Adaboost juga digunakan untuk mengenali identitas wajah seseorang setelah data wajah orang tersebut disimpan dalam suatu kumpulan (galeri) data latih. Pada tahap ini Machine Learning Adaboost mencocokan data input citra wajah dengan kumpulan data latih yang telah disimpan dalam galeri, secara berurutan setiap sample data latih dicocokan hingga akhirnya menemukan data wajah yang sesuai, data sample wajah yang tidak cocok langsung ditolak dan proses akan dilanjutkan pada data latih citra berikutnya. Selanjutnya masuk kedalam proses deteksi menggunakan metode cascade classifier Tahap selanjutnya yaitu cascade. Urutan filter pada cascade ditentukan oleh bobot yang diberikan AdaBoost. Filter dengan bobot paling besar diletakkan pada proses pertama kali, bertujuan untuk menghapus daerah gambar bukan wajah secepat mungkin.Tahapan yang terakhir adalah menampilakan objek sampel gambar yang telah terdeteksi wajah ataupun bukan wajah, dengan memberi tanda bujur sangkar jika objek tersebut dianggap sebagai daerah (region) wajah manusia.

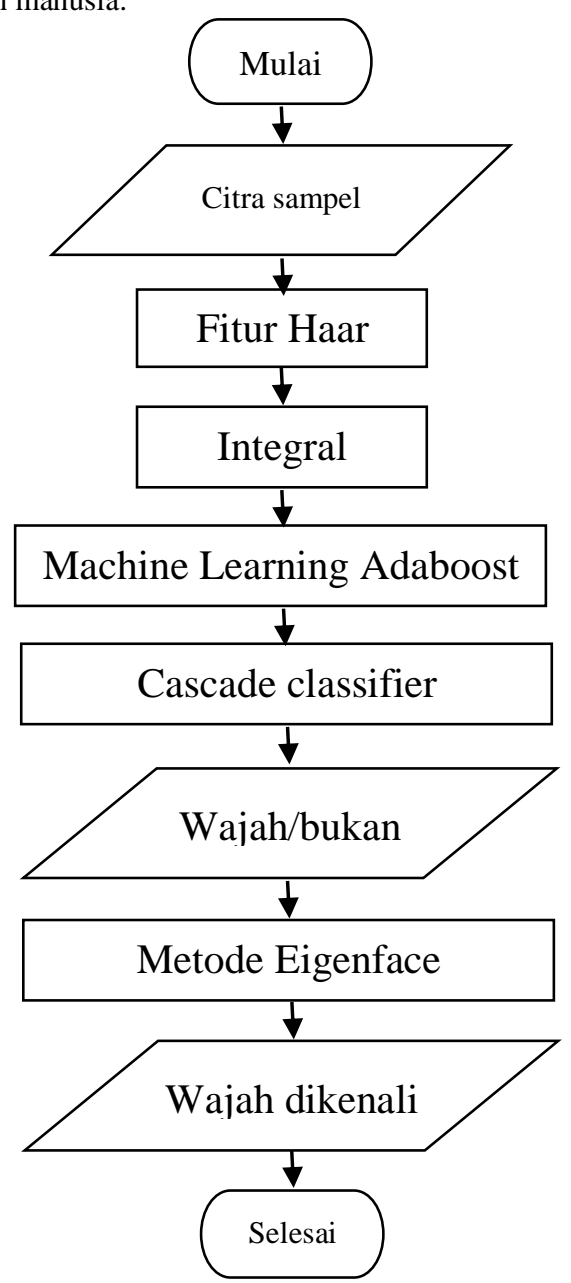

Gambar 1 Perancangan Sistem Penelitian metode viola jones 
Input capture Gambar (Realtime)

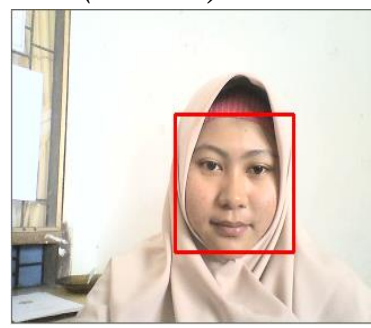

Gambar 2 Hasil Capture secara realtime

Proses Perubahan Sampel Gambar Wajah Menjadi Sampel gambar wajah terdeteksi dan dikenali.

\section{Input Gambar (Realtime)}

Proses pertama yaitu menangkap sampel gambar wajah manusia secara realtime lalu mendeteksi citra wajah manusia dengan memberi tanda bujur sangkar jika objek tersebut dianggap sebagai daerah (region) wajah manusia. Perhatikan gambar 3

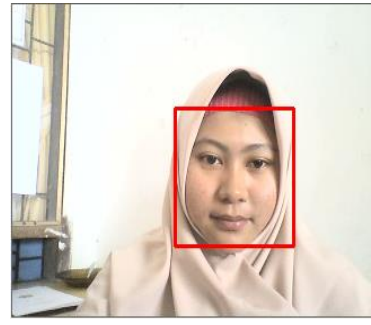

Gambar 3 Hasil capture secara realtime

\section{Proses Fitur Haar}

Fitur Haar adalah fitur yang digunakan dalam metode ViolaJonesyang dapat juga disebut fitur gelombang tunggal bujur sangkar (satu interval tinggi dan sat interval rendah), sedangkan untuk dua dimensi disebut sebagai satu terang dan satu gelap.Perhatikan gambar 3.4.

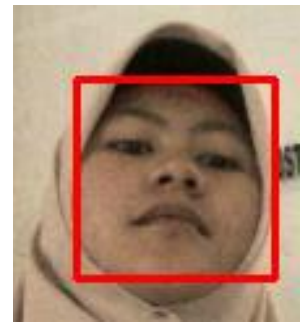

(a)

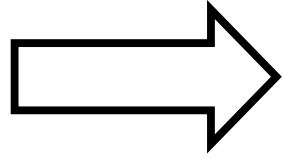

Pixel 10x10
Gambar 4 Proses Fitur Haar

\section{Proses Integral Image}

Integral Image adalah sebuah citra yang nilai tiap pikselnya merupakan penjumlahan dari nilai pixel kiri atas hingga kanan bawah. Integral image memungkinkan penghitungan pixel secara mudah dengan biaya yang murah, hitungan berdasarkan jumlah seluruh pixel yang terkandung dalam batasan jendela fitur haar, teknik pencerminan digunakan untuk distribusi fungsi kumulatif. Perhatikan gambar 5

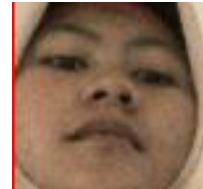

(a)

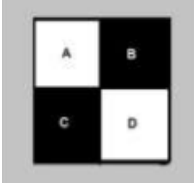

(b)

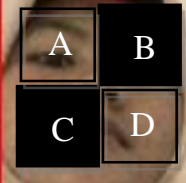

(c)
Gambar 5 Perhitungan Intergral Image

\section{Proses Machine Learning Adaboost}

Pada proses selanjutnya Machine Learning Adaboost juga digunakan untuk mengenali identitas wajah seseorang setelah data wajah orang tersebut disimpan dalam suatu kumpulan (galeri) data latih. Pada tahap ini Machine Learning Adaboost mencocokan data input citra wajah dengan kumpulan data latih yang telah disimpan dalam galeri, secara berurutan setiap sample data latih dicocokan hingga akhirnya menemukan data wajah yang sesuai, data sample wajah yang tidak cocok langsung ditolak dan proses akan dilanjutkan pada data latih citra berikutnya. Perhatikan gambar 3.6.

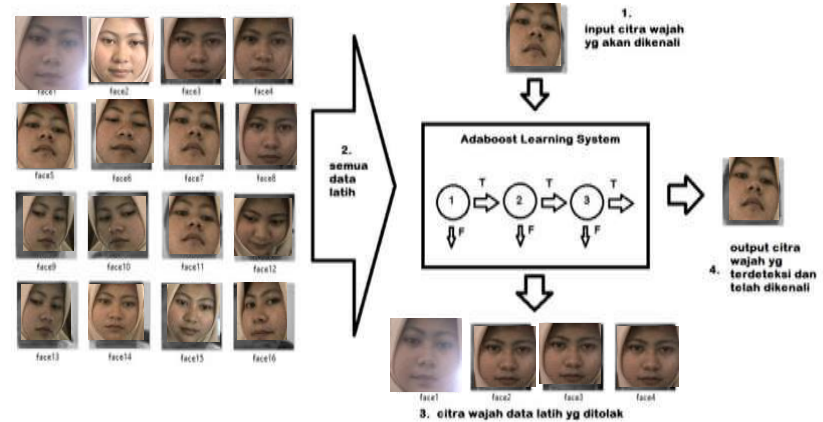

Gambar 6 Klasifikasi pencocokan data wajah pada Machine Learning Adaboost

\section{Proses Cascade Classifier}

Tahap selanjutnya yaitu cascade. Urutan filter pada cascade ditentukan oleh bobot yang diberikan AdaBoost. Filter dengan bobot paling besar diletakkan pada proses pertama kali, bertujuan untuk menghapus daerah gambar bukan wajah secepat mungkin.

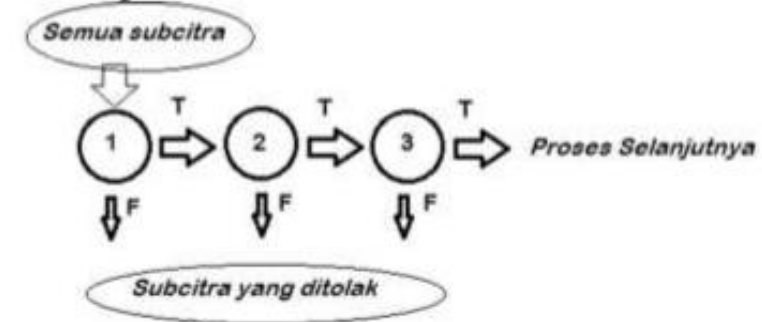

Gambar 7 Alur klasifikasi bertingkat (cascade)

\section{HASIL PERCOBAAN}




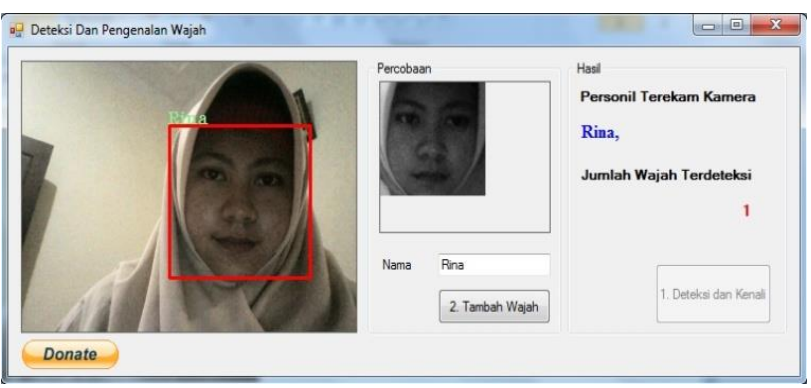

Gambar 8 Hasil percobaan

\section{KESIMPULAN}

1. Implentasikan metode Viola - Jones untuk mendeteksi citra wajah manusia dengan berbagai posisi citra wajah dapat dilakukan dengan bantuan perangkat webcam laptop.

2. Hasil deteksi wajah pada percobaan ini adalah menampilakan objek sampel gambar yang telah terdeteksi wajah ataupun bukan wajah, dengan memberi tanda bujur sangkar jika objek tersebut dianggap sebagai daerah (region) wajah manusia.

3. Machine Learning Adaboost mencocokan data input citra wajah dengan kumpulan data latih yang telah disimpan dalam galeri, secara berurutan setiap sample data latih dicocokan hingga akhirnya menemukan data wajah yang sesuai, data sample wajah yang tidak cocok langsung ditolak dan proses akan dilanjutkan pada data latih citra berikutnya.

4. Fitur Haar adalah fitur yang digunakan dalam metode ViolaJonesyang dapat juga disebut fitur gelombang tunggal bujur sangkar (satu interval tinggi dan sat interval rendah), sedangkan untuk dua dimensi disebut sebagai satu terang dan satu gelap.

5. Sebelum data citra sampel RGB tercapture secara realtime menggunakan webcam akan diolah menggunakan metode viola jones terlebih dahulu citra sampel RGB dikonversi mejadi citra grayscale dan citra grayscale dapt diproses menggunakan metode viola jones agar wajah manusia atau bukan terdeteksi.

6. Langkah selanjutnya jika wajah manusia terdeteksi kemudian data citra sampel manusia yang telah terdeteksi lalu hasil deteksi wajah dari metode viola jones selanjutnya dijadikan bahan untuk pengenalan wajah padametode Eigenface.

\section{DAFTAR PUSTAKA}

[1] Aditya Wisnu W I, Anthony F \& Andrian S (2009). Analisis dan Perancangan Sistem Identifikasi Berbasis Wajah dengan Menggunakan Pustaka Open CV. Jurusan Teknik Informatika-Universitas Binus

[2] Cho Junguk, Mirzaei Shahnam, Oberg Jason, \& Kastner Ryan (2009). FPGA-Based Face DeyectionSystem Using Haar Classifiers. Department of Computer Science and Engineering Universityof California, San Diego United States, \& Department of Electrical and Computer EngineeringUniversity of California, Santa Barbara, United states.
[3] Dwisnanto Putro M, Bharata Adji T, \& Winduratna B (2012). Deteksi Wajah dengan MenggunakanMetode ViolaJones. Magister Instrumentasi Elektro FT UGM. Seminar Nasional "Science,Engineering and Technology (SciETec).

[4] Eka Puspitasari D, Hidayatno A, \& Ajulian Zahra A. Pengenalan Wajah Menggunakan Metode PCAuntuk Aplikasi Sistem Keamanan Rumah. Jurusan Teknik Elektro Fakultas Teknik UniversitasDiponegoro, Semarang.

[5] Gunadi K \& Pongsitanan Reinard S. Pembuatan Perangkat Lunak Pengenalan Wajah Menggunakan PCA. Fakultas Teknologi Industri, Jurusan Teknik Informatika Universitas Kristen Petra.Jurnal Informatika Vol. 2, No. 2, Nov 2001:67-81. 